\title{
Antigenicity of Cell Wall Mannans of Candida albicans NIH A-207 Strain Cells Cultured in Galactose-Added Yeast Nitrogen Base Medium
}

\author{
Yoshio Okawa,* Masayoshi Miyauchi, Kouji Goto, and Philippe Giummelly \\ Second Department of Hygienic Chemistry, Tohoku Pharmaceutical University; 4-4-1 Komatsushima, Aoba-ku, Sendai, \\ Miyagi 981-8558, Japan. Received September 21, 2004; accepted November 19, 2004
}

\begin{abstract}
The cultivations of the Candida albicans NIH A-207 strain (A-strain) for $5 \mathrm{~d}$ at 27 and $37^{\circ} \mathrm{C}$ in $500 \mathrm{~mm}$ galactose-added yeast nitrogen base medium (YNB-Gal) decreased the growth of blastoconidia and the pH in the cultures, with dry weights of 56 and $47 \%$ and with pHs of 2.41 and 2.47 , compared with the dry weight of $100 \%$ and $\mathrm{pH}$ of 5.63 for a standard cultivation of $2 \mathrm{~d}$ at $27^{\circ} \mathrm{C}$ in the yeast extract-added Sabouraud liquid medium (YSLM). The cells obtained by cultivations at 27 and $37^{\circ} \mathrm{C}$ in the YNB-Gal clearly decreased the agglutination against serum factors 4,5 , and 6 in the commercially available kit 'Candida Check', especially at $37^{\circ} \mathrm{C}$, in contrast to those obtained by the standard cultivation. It was also revealed by ${ }^{1} \mathrm{H}-\mathrm{NMR}$ analysis that both the mannans obtained from cultures at 27 and $37^{\circ} \mathrm{C}$ in the YNB-Gal had drastically lost a phosphate group and a $\beta$-1,2linked mannopyranose unit, and increased the non-reducing terminal $\alpha$-1,3-linked mannopyranose unit, especially at $37^{\circ} \mathrm{C}$.
\end{abstract}

Key words Candida albicans; yeast nitrogen base (YNB)-galactose medium; mannan; antigenicity; structure

The adherence to host cells of Candida albicans is believed to play a critical role in the colonization of mucosal surfaces and subsequent infection. In 1981, Douglas et al. reported that yeast nitrogen base medium (Difco) containing $500 \mathrm{~mm}$ galactose (YNB-Gal) is useful for the studies of the adhesion to acrylic surfaces ${ }^{1)}$ and buccal epithelial cells ${ }^{2,3)}$ of C. albicans, and recently, of the biofilm formations. ${ }^{4}$ They and others ${ }^{5)}$ mentioned that the protein portrion of the mannoprotein adhesin of the yeast is more important than the carbohydrate moiety. On the other hand, in separate experiments, several authors have shown that the cell-wall mannan parts are implicated to have at least some adhesive function to the host cells. ${ }^{6-10)}$ In 1989 , we attempted the isolation of the adhesin from the $C$. albicans NIH A-207 strain (A-strain) using the YNB-Gal. At that time, we (Okawa and Giummelly, a private message) noticed that the cultures of the Astrain in the YNB-Gal had an acidic $\mathrm{pH} \mathrm{2-3}$, and an drastic changing of the structure of the mannan in the supernatant. By using the $\mathrm{pH}$ information, we investigated the antigenicities and the mannan structures of $C$. albicans cells cultured at the acidic $\mathrm{pH} 2.0,{ }^{11-13)}$ and then at the high temperatures of 37 and $40^{\circ} \mathrm{C},{ }^{14,15)}$ in yeast extract-added Sabouraud liquid medium (YSLM). Until now there have been no reports about the structures of the cell wall mannans of the A-strain cells cultured in YNB-Gal. In this paper, we describe the changes in the antigenicity and the chemical structure of the mannans.

\section{MATERIALS AND METHODS}

Strain and Culture Conditions The C. albicans NIH A-207 strain (A-strain) was kindly supplied by Dr. T. Shinoda, Meiji College of Pharmacy, Tokyo, Japan. The cultivation and preparation of cells were conducted as previously described. The A strain was precultured in yeast extractadded Sabouraud liquid medium (YSLM) at $27^{\circ} \mathrm{C}$ for $24 \mathrm{~h}$ on a rotary shaker $(150 \mathrm{rpm}){ }^{14)}$ The cells $\left(2 \times 10^{7}\right)$ in 100 to $200 \mu \mathrm{l}$ aliquots were then inoculated into each $200 \mathrm{ml}$ of YSLM and of yeast nitrogen base medium containing
$500 \mathrm{~mm}$ galactose (YNB-Gal) ${ }^{1)}$ in $500 \mathrm{ml}$ Erlenmeyer flasks, and the main cultivations were separately conducted at 27 and $37^{\circ} \mathrm{C}$ for 2 and $5 \mathrm{~d}$ with shaking. After harvesting the cells by centrifugation, the $\mathrm{pHs}$ of the supernatants were measured and the precipitated cells were washed three times with saline by centrifugation. The morphologies of the washed cells were photomicroscopically evaluated. To evaluate the cell density at the end of each culture period, portions of the cultures were freeze-dried. Cells washed with saline were dehydrated with a large volume of acetone.

Slide Agglutination Reaction Slide agglutination assays were conducted as described elsewhere ${ }^{16,17)}$ with suspensions of the heat-killed cells which were harvested after cultivation.

Preparation of Mannans Mannans were prepared as previously described. ${ }^{18)}$ Briefly, this was done by a combination of extraction with hot water and short-term precipitation with Fehling solution. The mannan fractions obtained from the A strain cultured at $27^{\circ} \mathrm{C}$ for $2 \mathrm{~d}$ in YSLM, at $27^{\circ} \mathrm{C}$ for $5 \mathrm{~d}$ in YNB-Gal, and at $37^{\circ} \mathrm{C}$ for $5 \mathrm{~d}$ in YNB-Gal were designated mannans A-27-M, Y-27-M, and Y-37-M, respectively.

${ }^{1} H$-NMR Analyses of the Mannans The ${ }^{1} \mathrm{H}-\mathrm{NMR}$ spectra were recorded using a JEOL JNM-GSX 400 spectrometer. Each sample was dissolved in $\mathrm{D}_{2} \mathrm{O}$ at a concentration of $1 \%$ (wt/vol), and the determination was conducted at $45^{\circ} \mathrm{C}$ with acetone as the internal standard (2.217 ppm).

\section{RESULTS AND DISCUSSION}

A comparison of the $\mathrm{pH}$ values and cell growth rates after cultivation of the A-strain in YSLM and YNB-Gal at different temperatures was conducted (Table 1). Cultivations of the A-strain for $5 \mathrm{~d}$ at 27 and $37^{\circ} \mathrm{C}$ in YNB-Gal decreased the growth of the blastoconidia and the $\mathrm{pH}$ in the cultures, with dry weights of 56 and $47 \%$ and with pHs of 2.41 and 2.47 , compared with the dry weight of $100 \%$ and $\mathrm{pH}$ of 5.63 in a standard cultivation of $2 \mathrm{~d}$ at $27^{\circ} \mathrm{C}$ in YSLM. The A-strain cells cultivated in YNB-Gal for $5 \mathrm{~d}$ at 27 and $37{ }^{\circ} \mathrm{C}$ grew in the budding yeast phase. ${ }^{1-3)}$ We already reported that the 
Table 1. Measurement of $\mathrm{pH}$ and Cell Growth in Cultures of A-Strain Cells Grown at Several Conditions

\begin{tabular}{|c|c|c|c|c|}
\hline \multirow{2}{*}{ Medium } & \multirow{2}{*}{$\begin{array}{c}\text { Growth temp. } \\
\left({ }^{\circ} \mathrm{C}\right)\end{array}$} & \multirow{2}{*}{$\begin{array}{l}\text { Incubation period } \\
\text { (d) }\end{array}$} & \multicolumn{2}{|r|}{ Cultures } \\
\hline & & & $\mathrm{pH}$ & $\begin{array}{c}\text { Cell growth } \\
\text { (dry weight, g/l) }\end{array}$ \\
\hline YSLM & 27 & 2 & 5.63 & 4.94 \\
\hline YNB-Gal & 27 & 5 & 2.41 & 2.79 \\
\hline YNB-Gal & 37 & 5 & 2.47 & 2.33 \\
\hline
\end{tabular}

Table 2. Slide Agglutination of A-Strain Cells Grown at Several Conditions with Polyclonal Anti-factor Sera

\begin{tabular}{|c|c|c|c|c|c|c|}
\hline \multirow{2}{*}{ Medium } & \multirow{2}{*}{$\begin{array}{l}\text { Growth temp. } \\
\qquad\left({ }^{\circ} \mathrm{C}\right)\end{array}$} & \multirow{2}{*}{$\begin{array}{l}\text { Incubation period } \\
\text { (d) }\end{array}$} & \multicolumn{4}{|c|}{ Factor serum } \\
\hline & & & 1 & 4 & 5 & 6 \\
\hline YSLM & 27 & 2 & +++ & +++ & +++ & +++ \\
\hline YNB-Gal & 27 & 5 & +++ & ++ & + & + \\
\hline YNB-Gal & 37 & 5 & +++ & + & \pm & \pm \\
\hline
\end{tabular}

Agglutination was scored from high $(+++)$ to very low $( \pm)$, and no agglutination $(-)$.

A-strain cells decreased the growth rate by both the changes in $\mathrm{pH}, \mathrm{pH} 5.6$ to $2.0,{ }^{11)}$ and temperatures, $27^{\circ} \mathrm{C}$ to 37 and $40{ }^{\circ} \mathrm{C}$, ${ }^{14)}$ in YSLM. Based on the present results, we can state that the cell growth of the A-strain in the YNB-Gal was influenced by the severe conditions such as the low nutrition, the acidic $\mathrm{pH}$, and the high temperature.

We then performed a series of agglutination tests between serum factors from a commercially available serum factor kit (Candida Check). ${ }^{16,17)}$ and cells from the A strain grown in YNB-Gal at 27 and $37^{\circ} \mathrm{C}$ and in YSLM at $27^{\circ} \mathrm{C}$ (Table 2). The cells obtained by cultivations at 27 and $37^{\circ} \mathrm{C}$ in the YNB-Gal clearly decreased the agglutination against factor sera 4,5 , and 6 , and retained the reactivity with factor serum 1 , in contrast to those obtained by the standard cultivation in YSLM. These results show that the changes in antigenicity, namely, in the mannan structure, of the A-strain cells are caused by cultivation in YNB-Gal.

We next determined the chemical structure of the mannans by ${ }^{1} \mathrm{H}-\mathrm{NMR}$ (Fig. 1). Both mannans (Y-27-M and Y-37-M) obtained from the A-strain cells cultured at 27 and $37^{\circ} \mathrm{C}$ in the YNB-Gal had lost a phosphate group, the 1-O-phosphorylated mannose unit, 5.535 and $5.552 \mathrm{ppm}$, and a $\beta$-1,2linked mannopyranose unit, 4.776, 4.843, and $4.854 \mathrm{ppm}$, especially Y-37-M, but increased the internal $\alpha$-1,2-linked mannopyranose unit, $5.287-5.288 \mathrm{ppm}$, the internal $\alpha-1$, 6-linked mannopyranose unit, $5.095 \mathrm{ppm}$, substituted by the $\alpha$-1,2-linked one, and the internal $\alpha$-1,6-linked mannopyranose unit, $4.910 \mathrm{ppm}^{13)}$ The non-reducing terminal $\alpha-1$, 3 -linked mannopyranose unit, $5.135 \mathrm{ppm}$, clearly appeared in Y-37-M instead of the $\alpha-1,2$-linked mannopyranose unit, $5.145 \mathrm{ppm}$, substituted by the $\beta$-1,2-linked oligomannosyl unit in A-27-M. Y-37-M clearly lost the reactivity to factor sera 5 and 6 , because these sera recognize the side chains containing the $\beta$-1,2-linked mannose residues. ${ }^{14,15,19,20)}$ The $\alpha$-1,6-branched mannopyranose unit, $5.235 \mathrm{ppm}$, of Candida mannan functions as the determinant of the antigenic factor 4. ${ }^{19)}$ As all three mannans used in this experiment contain nealy the same amounts of the branched side chain, it seems that the differences of the reactivity with the factor serum 4

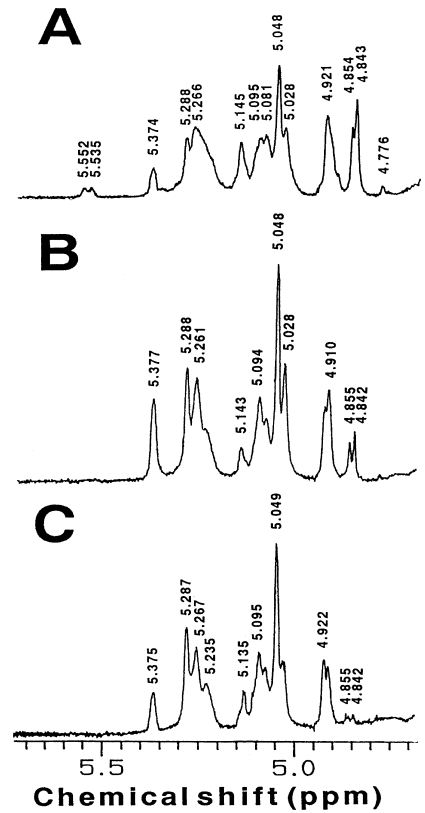

Fig. 1. ${ }^{1} \mathrm{H}-\mathrm{NMR}$ Spectra of Mannans of A-Strain Cells Grown at Several Conditions

A, A-27-M; B, Y-27-M; C, Y-37-M.

depend on the remaining amounts of $\beta$-1,2-linked mannopyranose units in the mannans as discussed in the preceeding paper. ${ }^{14,15)}$ Serum factor 1 has been shown to recognize the $\alpha$-1,2-linked oligonannosyl side chains in mannan. ${ }^{13,15)}$ The three mannans have significantly the non-reducing terminal $\alpha$-1,2-linked mannopyranose unit, 5.048-5.049 ppm, and the internal $\alpha-1,2$-linked mannose unit, 5.287-5.288 ppm. This is the reason that the three mannans have the same reactivity with factor serum 1.

Based on these results, we can state that most of the structures of the mannans obtained from the A-strain cells cultivated in YNB-Gal consist of the $\alpha$-mannosyl residues. This finding may influence the properties of Candida cells cultivated in YNB-Gal. It is also very similar to the antigenicities and the mannan structures of the $C$. albicans serotype A strain cells cultured at the acidic $\mathrm{pH} 2.0,{ }^{11-13)}$ and at the high temperatures of 37 and $40^{\circ} \mathrm{C}^{14)}$ in YSLM. Therefore, the present results seem to indicate that transferase activities participating in the introduction of mannosylphosphate and $\beta$-1,2-linked mannopyranose units underwent inactivation by culturing in YNB-Gal. ${ }^{21)}$ Detailed studies of these mannosyltransferases of Candida species is now in progress.

It is possible to mention that the mannan obtained from C. albicans cells by cultivation for $5 \mathrm{~d}$ in YNB-Gal changed the antigenicities and the mannan structures by changing not only the $\mathrm{pH}$ but also the temperature (Tables 1, 2, Fig. 1). We also have obtained the same structured mannan fractions as Y-37-M in the supernatant of the C. albicans cultures in YNB-Gal (unpublished data). It has been known that the growth in a high-galactose medium (YNB-Gal) promotes the synthesis of an mannoprotein adhesin, resulting in increased adhesion to the various animall cells. ${ }^{2,3,5)}$ The results of the present YNB-Gal study seem to be useful for determining the structure and the function of the mannoprotein adhesin. 


\section{REFERENCES}

1) McCourtie J., Douglas L. J., Infect. Immun., 32, 1234-1241 (1981).

2) Douglas L. J., Houston J. G., McCourtie J., FEMS Microbiol. Lett., 12, 241-243 (1981).

3) Critchley I. A., Douglas L. J., J. Gen. Microbiol., 133, 629-636 (1987).

4) Hawser S. P., Douglas L. J., Infect. Immun., 62, 915-921 (1994).

5) Enache E., Eskandari T., Borja L., Wadsworth E., Hoxer B., Calderone R., Microbiology, 142, 2741-2746 (1996).

6) Miyakawa Y., Kuribayashi T., Kagaya K., Suzuki M., Nakase T., Fukazawa Y., Infect. Immun., 60, 2493-2499 (1992).

7) Li R.-K., Cutler J. E., J. Biol. Chem., 268, 18293-18299 (1993).

8) Kanbe T., Cutler J. E., Infect. Immun., 62, 1662-1668 (1994).

9) Masuoka J., Hazen K. C., Microbiology, 143, 3015-3021 (1997).

10) Fradin C., Poulain D., Jouault T., Infect. Immun., 68, 4391-4398 (2000).

11) Kobayashi H., Giummelly P., Takahashi S., Ishida M., Sato J., Takaku M., Nishidate Y., Shibata N., Okawa Y., Suzuki S., Biochem. Biophys. Res. Commun., 175, 1003-1009 (1991).

12) Kobayashi H., Takahashi S., Shibata N., Miyauchi M., Ishida M., Sato
J., Maeda K., Suzuki S., Infect. Immun., 62, 968 -973 (1994).

13) Kobayashi H., Tanaka S., Suzuki J., Kiuchi Y., Shibata N., Suzuki S., Okawa Y., FEMS Microbiol. Lett., 152, 235-242 (1997).

14) Okawa Y., Takahata T., Kawamata M., Miyauchi M., Shibata N., Suzuki A., Kobayashi H., Suzuki S., FEBS Lett., 345, 167-171 (1994).

15) Okawa Y., Goto K., Nemoto S., Akashi M., Sugawara C., Hanzawa M., Kawamata M., Takahata T., Shibata N., Kobayashi H., Suzuki S., Clin. Diagn. Lab. Immunol., 3, 331-336 (1996).

16) Fukazawa Y., Shinoda T., Tsuchiya T., J. Bacteriol., 95, 754-763 (1968).

17) Shinoda T., Kaufman L., Padhye A. A., J. Clin. Microbiol., 13, 513518 (1981).

18) Kobayashi H., Shibata N., Mitobe H., Ohkubo Y., Suzuki S., Arch. Biochem. Biophys., 272, 364-375 (1989).

19) Suzuki S., Curr. Top. Med. Mycol., 8, 57-70 (1997).

20) Okawa Y., Monma K., Shibata N., Kobayashi H., Yamada Y., Carbohydr. Res., 338, 1175-1182 (2003).

21) Okawa Y., Goto K., Book of Abstracts, The 22nd International Carbohydrate Symposium, Glasgow, UK, 2004, P40. 